\title{
Design and Construction of a Resistive Energy Dump Device for Bipolar Superconducting Magnet Systems
}

\author{
Martin J. Mohan \\ 1 NOTIGE
}

PORTIONS OF THIS REPORT ARE ILLEGTBLE. IC has been reproduced from the best available copy to permit the broadest possible availability.

\section{OAK RIDGE NATIONAL LABORATORY}

OPERATED BY UNION CARBIDE CORPORATION FOR THE ENERGY RESEARCH AND DEVELOPMENT ADMINISTRATION 


\section{DISCLAIMER}

This report was prepared as an account of work sponsored by an agency of the United States Government. Neither the United States Government nor any agency Thereof, nor any of their employees, makes any warranty, express or implied, or assumes any legal liability or responsibility for the accuracy, completeness, or usefulness of any information, apparatus, product, or process disclosed, or represents that its use would not infringe privately owned rights. Reference herein to any specific commercial product, process, or service by trade name, trademark, manufacturer, or otherwise does not necessarily constitute or imply its endorsement, recommendation, or favoring by the United States Government or any agency thereof. The views and opinions of authors expressed herein do not necessarily state or reflect those of the United States Government or any agency thereof. 


\section{DISCLAIMER}

Portions of this document may be illegible in electronic image products. Images are produced from the best available original document. 


\section{Printed in the United States of America. Available from National Technical Information Service \\ U.S. Department of Commerce \\ 5285 Port Royal Road, Springfield, Virginia 22161 \\ Price: Printed Copy $\$ 4.00$; Microfiche $\$ 3.00$}

This report was prepared as an account of work sponsored by the United States Government. Neither the United States nor the Energy Research and Development Administration/United States Nuclear Regulatory Commission, nor any of their employees, nor any of their contractors, subcontractors, or their employees, makes any warranty, express or implied, or assumes any legal liability or responsibility for the accuracy, completeness or usefulness of any information, apparatus, product or process disclosed, or represents that its use would not infringe privately owned rights. 
Contract No. W-7405-eng-26

FUSION ENERGY DIVISION

DESIGN AND CONSTRUCTION OF A RESISTIVE ENERGY

DUMP DEVICE FOR BIPOLAR SUPERCONDUCTING MAGNET SYSTEMS

Martin J. Mohan

Date Published: May 1977

NoTIr.e This decument containc information of e preliminaiy indule. It is subject to revision or correction and therefore does not represent a final report.

This report was prepared as an account of work sponsored by the United States Gover nment. Neither Denes their employses nor any of their contractors, subcontractors, or their employees, makes any Aracy, completeness of uxfulness of any information, apparatus, product of process disctosed, or represents anl its use wolld not infringe privately owned rights. 
THIS PAGE

\section{WAS INTENTIONALLY \\ LEFT BLANK}




\section{ABSTRACT}

When superconducting magnets quench, the resistance of the conductor material rises rapidly to its normal value. This increase in resistance can result in catastrophic heating in the magnet unless stored field energy is quickly removed from the system.

Phase inversion is the normal mode of energy removal. SCR's in the power supply are phased back, the output of the supply is inverted, and magnetic field energy is directed back into the utility grid.

Under certain conditions, however, the power supply may fail to invert properly, and an alternate energy removal scheme must protect the superconducting magnet system. Composed of an isolation switch, a semiconductor switching module, and a dump resistor, the resistive dump device provides a viable protection scheme.

Operationally, several conditions are capable of activating the isolation switch and triggering the bipolar SCR switching module. Manual dump commands, for instance, permit the operator to dump field energy in the event of observed abnormalities. A special voltage tap quench detector senses the aforementioned abnormal power supply output inversion and also fires the dump circuit.

Regardless of the nature of the trigger input, however, activation of the energy dump device diverts coil current through the dump resistor. $I^{2} R$ losses over time then safely dissipate stored magnetic field energy. 
THIS PAGE

WAS INTENTIONALLY

LEFT BLANK 


\section{v}

\section{ACKNOWLEDGMENTS}

The author would like to thank Mr. R. E. Schwall, of the Superconducting Magnet Development Division at Oak Ridge National Laboratory, for his help in defining design parameters and providing technical information on superconductor theory. Mr. E. W. Pipes, of the Y-12 Plant Electrical Engineering Department, also deserves special recognition for his tireless assistance and seemingly limitless technical expertise. $\mathrm{Mr}$. Pipes developed the semiconductor switching circuit at the heart of the dump device. 


\section{THIS PAGE \\ WAS INTENTIONALLY \\ LEFT BLANK}




\section{CONTENTS}

ABSTRACT ........................ $i$.

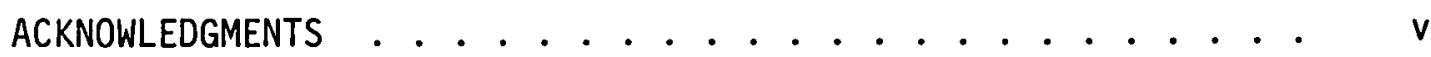

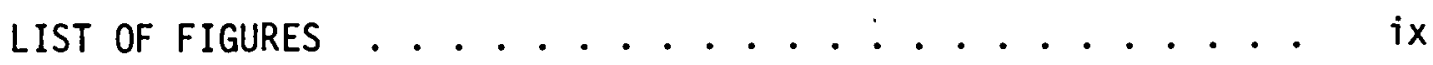

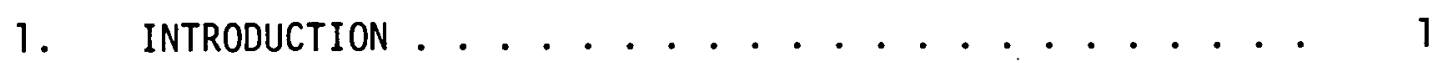

2. THE ENERGY DUMP DEVICE .................. 3

2.1 THE SEMICONDUCTOR SWITCHING MODULE ....... 3

2.1.1 Design Considerations ........ 3

2.1 .2 Construction . . . . . . . . . 7

2.2 THE DUMP RESISTOR . . . . . . . . . . . . 10

2.2.1 Operating Parameters ........ 10

2.2.2 Construction . . . . . . . . . . . . 10

2.3 THE ISOLATION BREAKER ............... 14

2.3.1 Design Considerations ......... 14

2.3.2 Isolation Breaker Operating Parameters . . . 14

3. DUMP STAGING ....................... 16

3.1 TRIGGER INPUTS . . . . . . . . . . . . . 16

3.2 DESCRIPTION OF CIRCUIT OPERATION . . . . . . 16

4. CONCLUSION ...................... 21

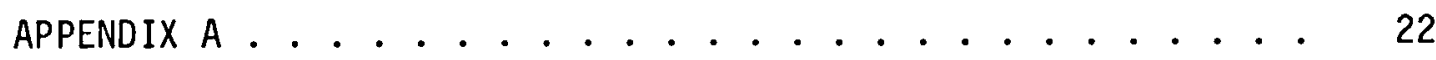

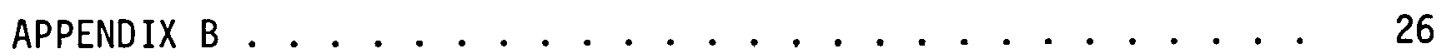

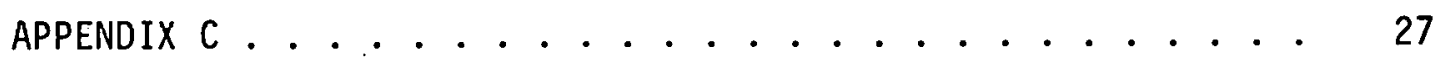

REFERENCES ..................... 30 


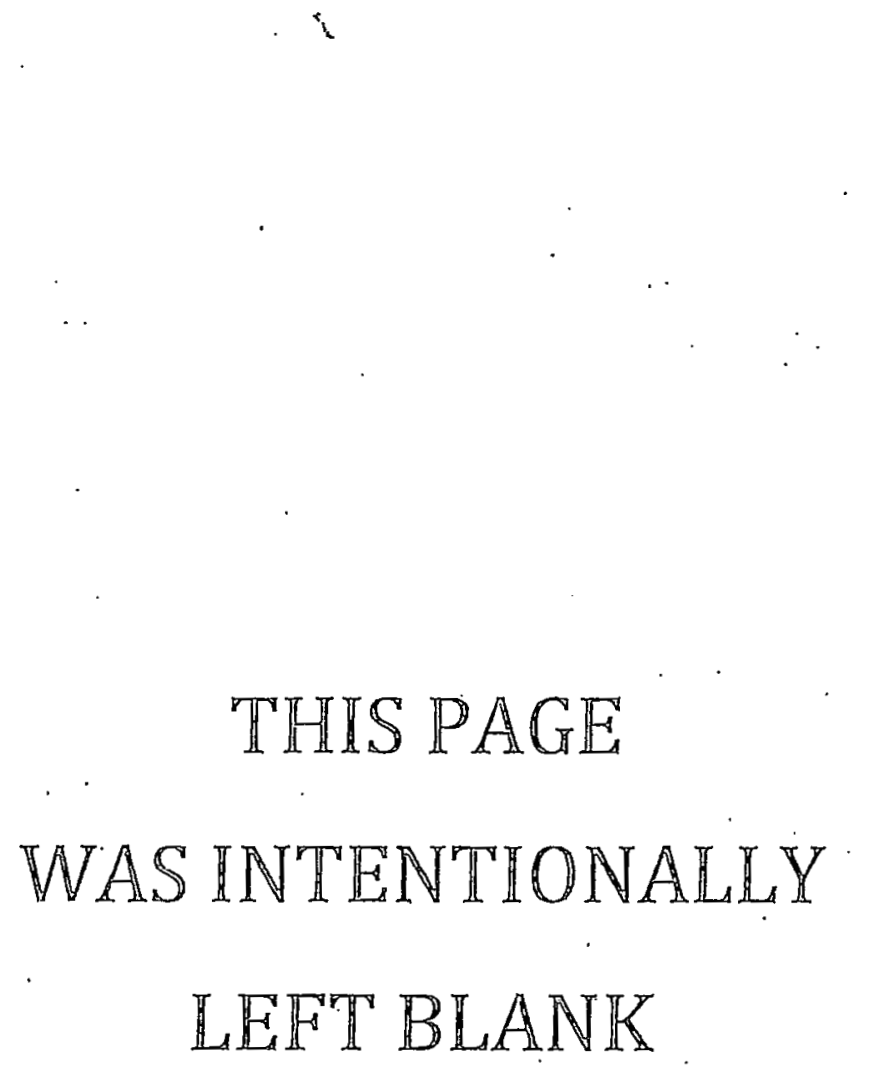




\section{LIST OF FIGURES}

\section{Figure}

Critical J-H-T Surface Separating

Normal and Superconductive Conductor Regions . . . . 2

Assembly of the Dump Device . . . . . . . . . . 4

Dump Device Control Elementary

Diagram (See Appendix C) . . . . . . . . . . 5

SCR Power Dissipation Curves. . . . . . . . . 6

SCR Thermal Circuit .............. . 8

Assembly of the Switching Module. . . . . . . . 9

Construction Procedures for the

Switching Module .. . . . . . . . . . . 11

Dissipation Curves . . . . . . . . . . . 12

Dump Resistor Support Detail............ 13

Switching Module Construction Details . . . . . . . 17

Quench Detector Block Diagram ........... 19 


\section{INTRODUCTION}

Superconducting materials are bounded in their resistanceless behavior by critical values of temperature, magnetic field and current density (See Figure 1) which, if exceeded, cause the superconductor to quench or return to its normal conducting state. ${ }^{1}$ When present in magnet systems, the quenched superconductor creates a serious problem in dealing with energy stored in the field of the magnet. Unless current in normal portions of the magnet is shunted to a highly conductive normal conductor (usually copper) surrounding the superconductor and field energy is quickly and safely removed from the system, catastrophic heating may result. ${ }^{2}$ In the event of failure of phase inversion techniques where field energy is fed back into the utility grid, energy dissipation in the superconducting magnet system described must occur through an appropriate energy dump device. 


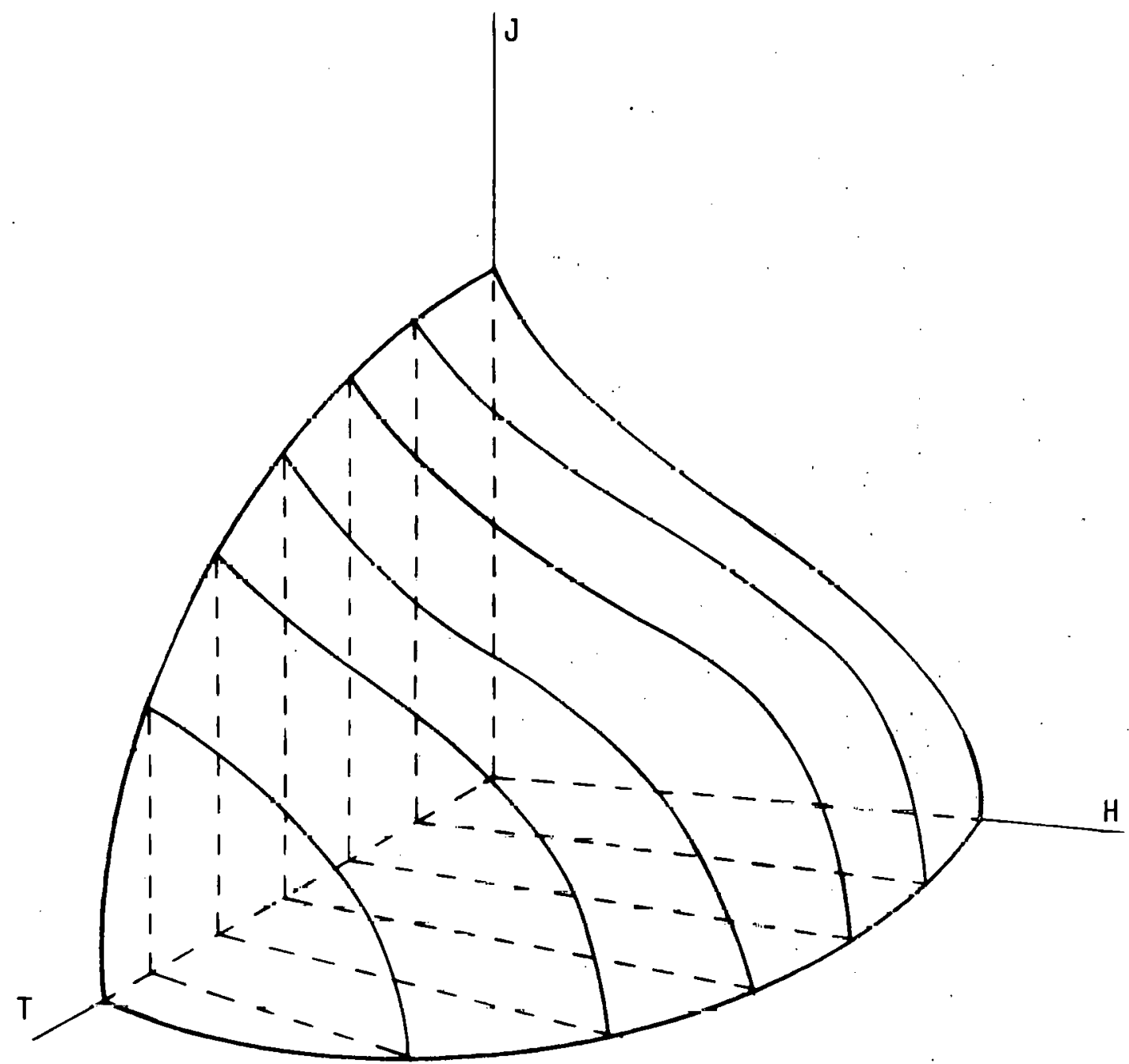

Fig. 1. Superconducting region bounded by critical J-H-T surface. Superconducting region below surface, resistive "nurmal" region above surface. (From Ref. 3) 


\section{THE ENERGY DUMP DEVICE}

The circuit described is designed for use with a $2 \mathrm{kA}, 300 \mathrm{~V}$ bipolar power supply. The three major elements of the dump device are a semiconductor switch, a dump resistor, and a $13.8 \mathrm{kV}$ ac circuit breaker used as an isolation switch. (See Figure 2)

\subsection{THE SEMICONDUCTOR SWITCHING MODULE}

\subsubsection{Design Considerations}

The purpose of the semiconductor switch is to provide a path for coil current through the dump resistor. See Figure 3 . Because of the bipolar nature of the power supply, the switch must be capable of accommodating current in two directions but not short the output of the supply under normal operating conditions. Also, the switch must have a minimum forward blocking voltage greater than $300 \mathrm{~V}$ and be capable of enduring a current decaying exponentially from $2000 \mathrm{~A}$ at a maximum time constant of 3 seconds.

The switching device chosen was a Westinghouse Type T920 Pow-R-Disc SCR, manufacturer's number T920121003 DW.* Data sheets are contained in Appendix A.

The rated $1200 \mathrm{~V}$ maximum forward blocking voltage of the device well exceeds minimum design requirements. It will be noted, however, that the device is rated for 1000 A average and 1570 A RMS forward current. It was therefore necessary to determine whether or not the junction temperature of the SCR would rise unacceptably during a dump procedure.

A worst case estimate of temperature rise was made by converting the power input curve shown in Figure $4 a$ to the series of pulses shown. in Figure $4 \mathrm{~b}$ as described in reference 4 . Next, the transient thermal impedance of the SCR and thermal impedance between the SCR case and heatsink were determined from manufacturer's data.

\footnotetext{
* Reference to a company or product name does not imply approval or recommendation of the product by Union Carbide, the Oak Ridge National LaboraLury, or the U. S. Energy Research and Development Administration to the exclusion of others that may be suitable, equal, or superior.
} 


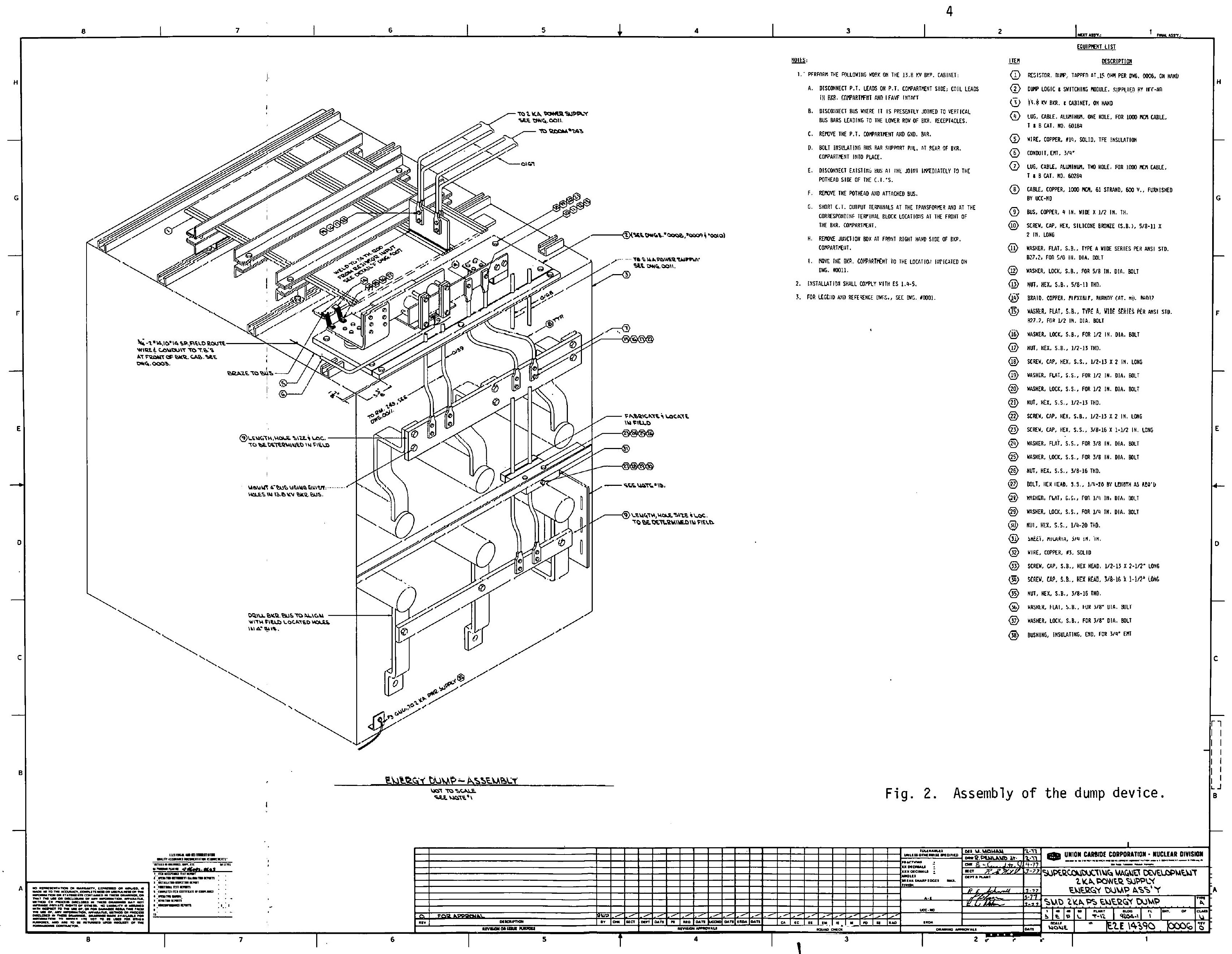




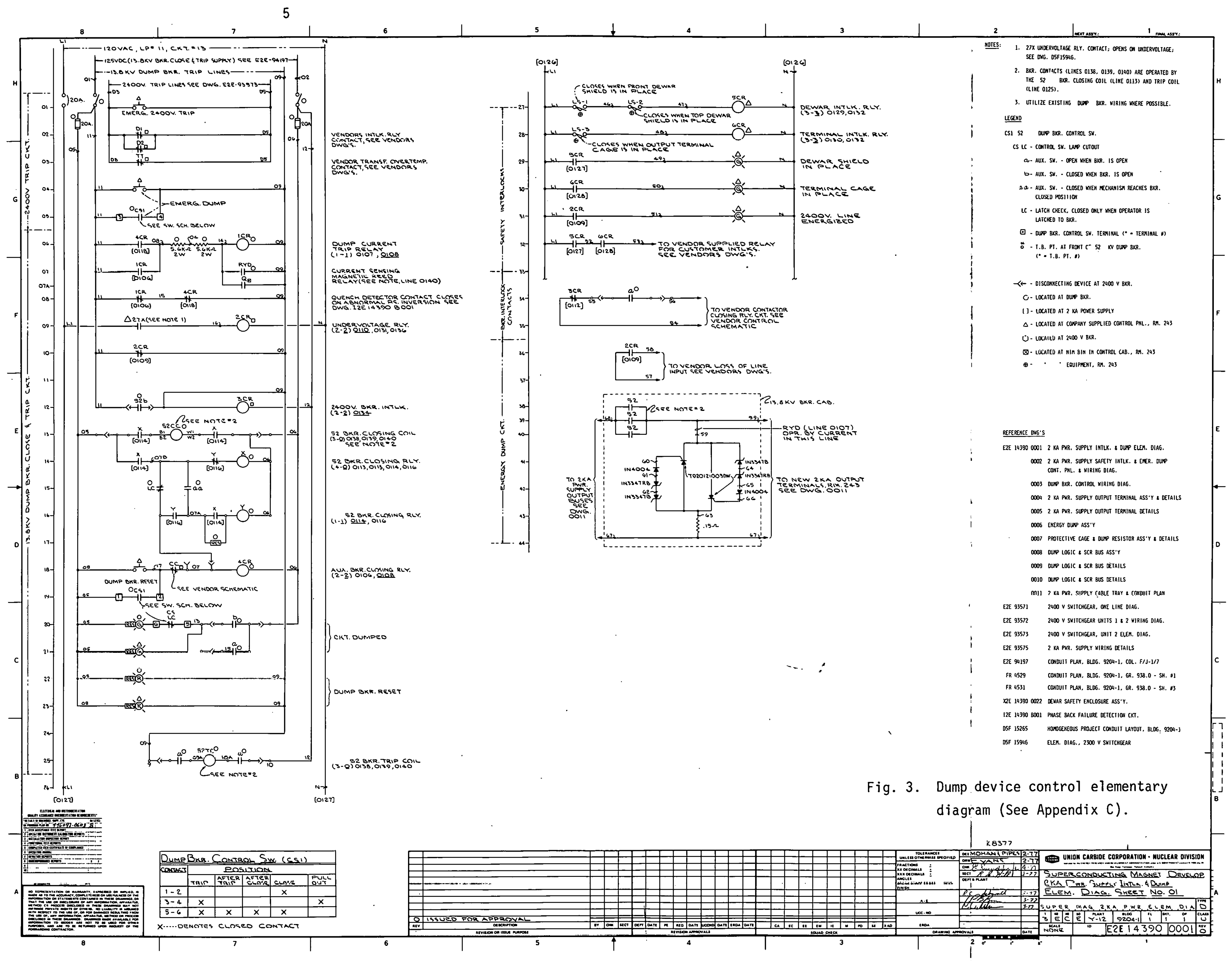




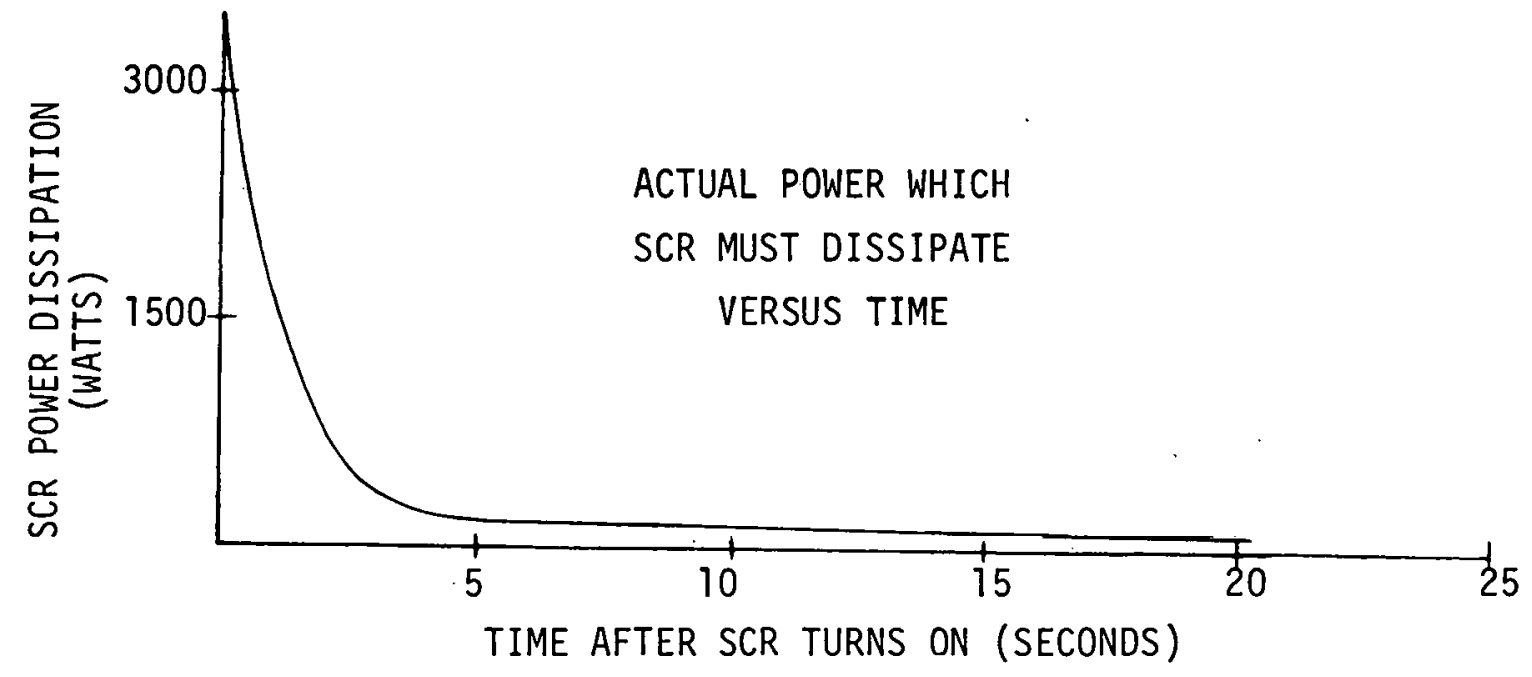

(a)

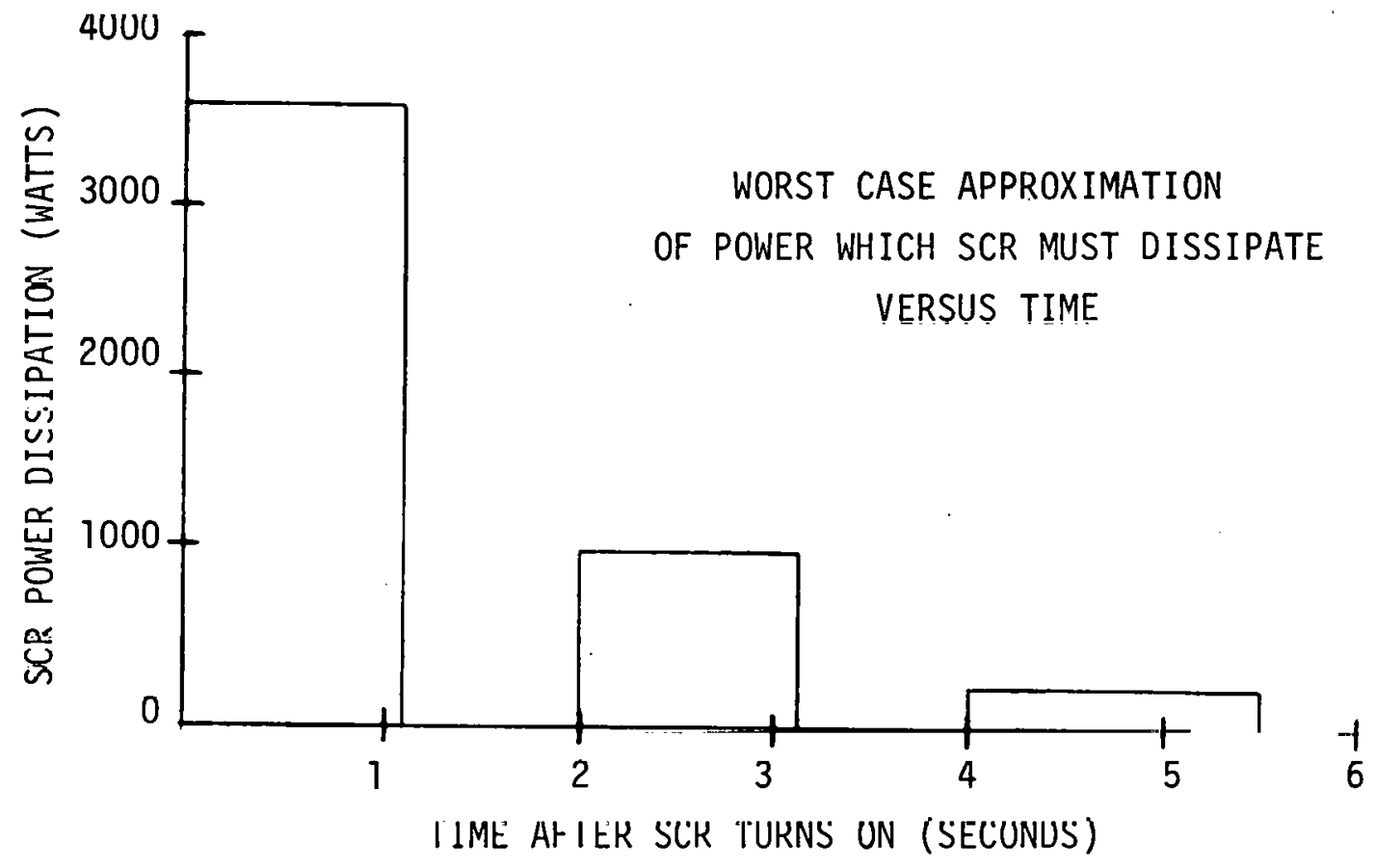

(b)

Fig. 4. Actual and Approximated SCR Power Uissipation Versus Time. 
In order to complete the thermal circuit of the SCR and to calculate a junction temperature rise, characteristics of the heatsink were considered. Transient thermal impedance of the heatsink, $\theta(t) F$, was calculated from the expression:

$$
{ }^{\theta}(t) F=\frac{1}{h \times A}\left(1-e^{-t / R C}\right){ }^{\circ} C / \text { Watt, }
$$

where $h$ is the total heat transfer coefficient of the heatsink in watts $/$ in $^{2}-{ }^{\circ} \mathrm{C}, \mathrm{A}$ is the sink's surface area in $\mathrm{in}^{2}$ and $\mathrm{RC}$ is the thermal time constant of the system in seconds. Substituting known values for $A$ and $R C,{ }^{\theta}(t) F$, was expressed as a function of $h$. A graph of the relation, however, indicates $\theta(t) \mathrm{F}$ varies only approximately $1 \times 10^{-5}{ }^{\circ} \mathrm{C} /$ watt while $\mathrm{h}$ varies from $10^{-8}$ to $10^{-2}$ watt $/ \mathrm{in}^{2}-{ }^{\circ} \mathrm{C}$. The short electrical time constant of the circuit thus limits the significance of heatsink configuration. After approximating $h$ from nomographs in reference 4 to insure $10^{-8}<h<10^{-2}, \theta(t) F$ was es timated at $1.5 \times 10^{-3}{ }^{\circ} \mathrm{C} /$ watt.

The complete thermal circuit is shown in Figure 5 . Calculation indicates that with $\mathrm{T}_{\text {ambient }}=25^{\circ} \mathrm{C}$, the SCR junction temperature will rise to a maximum of $122.4^{\circ} \mathrm{C}$. No junction overheating difficulties are therefore foreseen as maximum rated junction temperature is $125^{\circ} \mathrm{C}$ and the estimate is based on a wopst case.

Finally, a symmetrical switch assembly, described more fully under "Description of Circuit 0peration", allows the required bidirectional dump current.

\subsubsection{Construction}

An assembly view of the SCR switch is shown in Figure 6 . A modular concept was adopted so that the device could be assembled and tested under controlled conditions.

The base of the switching module is one inch thick laminated phenolic board. The $L$ shaped end brackets are held by 6 inch high 


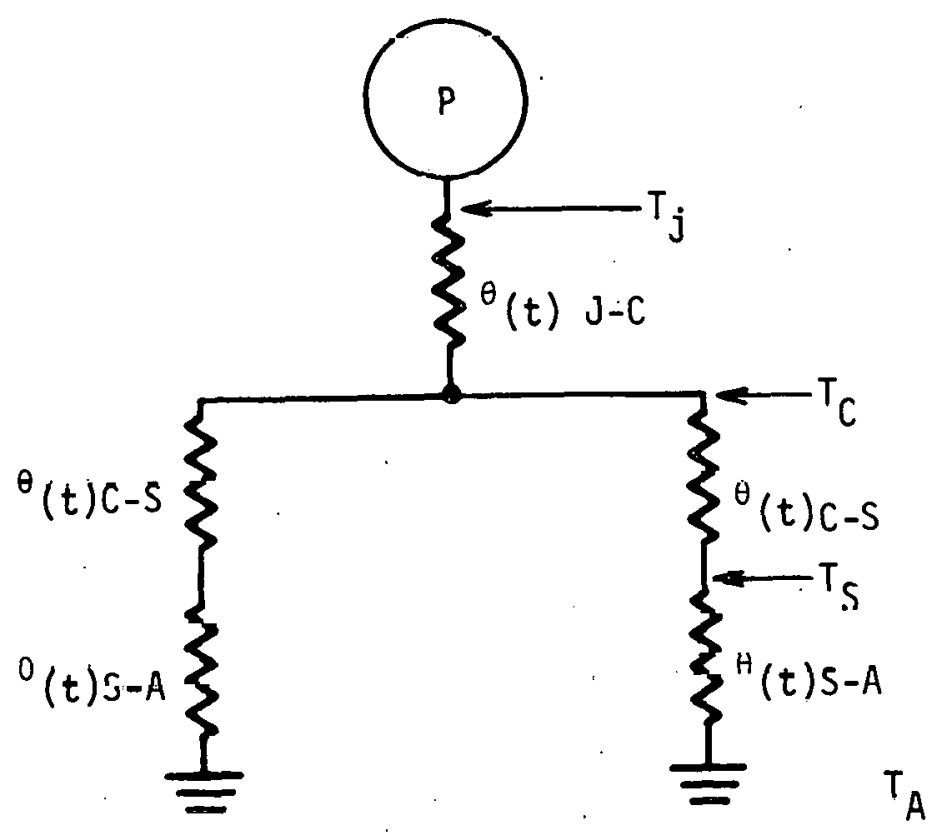

$P=S C R$ power dissipation, Watts; See Fig. $3 b$.

${ }^{\theta}(t) J-C=$ Transient thermal impedance between SCR junction \& case See Appendix A.

${ }^{\theta}(t) C-S$ - Transicnt thermal impendarice belweell case \& heatsink $\approx 0.01{ }^{\mathrm{U}} \mathrm{C} /$ Watt.

${ }^{\theta}(t) S-A=$ Transient thermal impedance between heatsink \& ambient $\approx 0.0015^{\circ} \mathrm{C} /$ Watt.

$T_{j}=$ junction temperature, ${ }^{\circ} \mathrm{C}$

$T_{C}=S C R$ case temperature, ${ }^{\circ} \mathrm{C}$

$T_{S}=$ heatsink temperature, ${ }^{\circ} \mathrm{C}$

$\mathrm{T}_{\mathrm{A}}=$ ambient temperature, ${ }^{\circ} \mathrm{C}$

Fig. 5. SCR Thermal Circuit. 


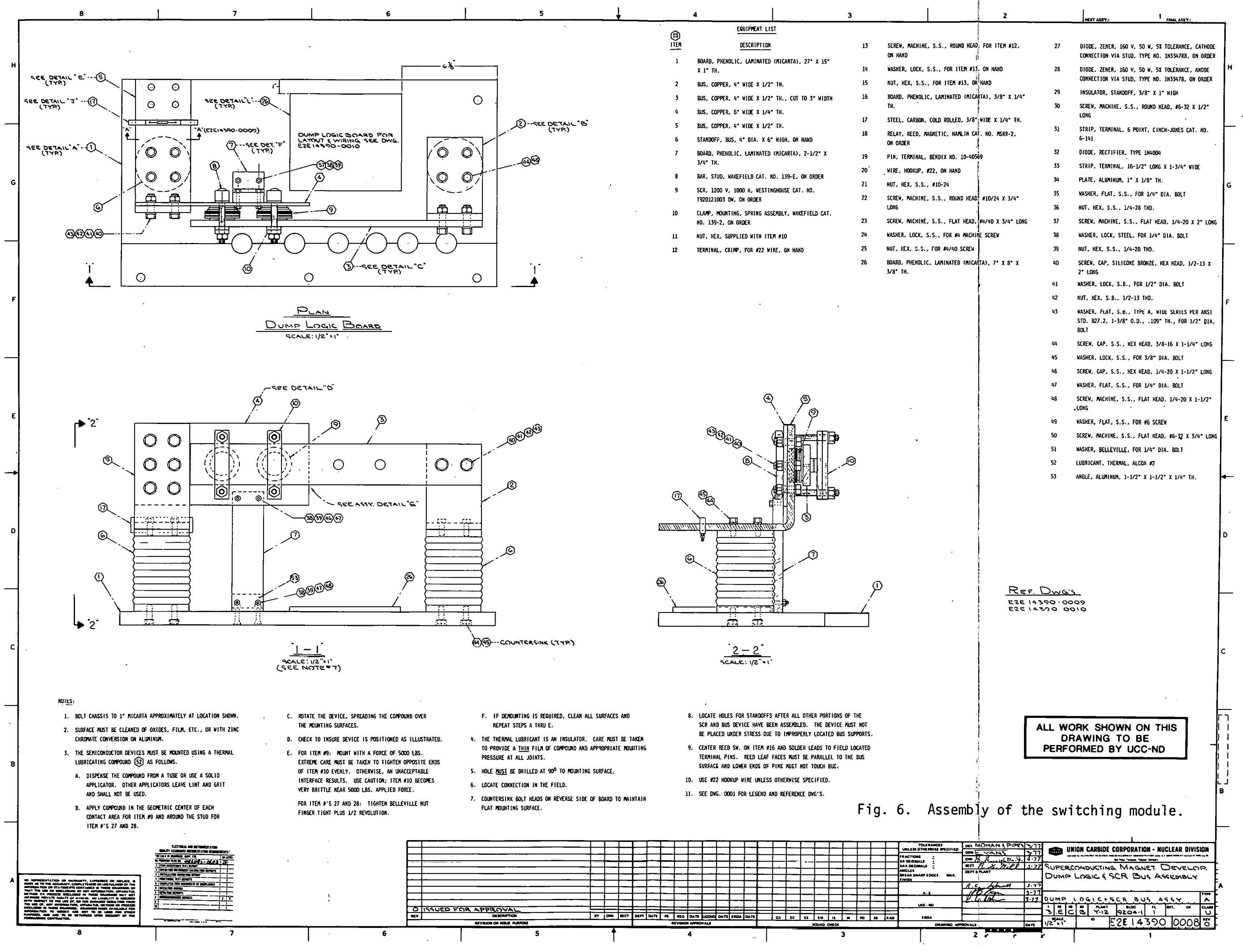


porcelain bus supports. The vertical bus bars which make electrical and thermal connection to the SCR's are prepared per Figure 7. Assembly procedures are extremely important and manufacturer's recommendations must be followed to prevent excess thermal and electrical impedance at the SCR case to heatsink junction.

\subsection{THE DUMP RESISTOR}

\subsubsection{Operating Parameters}

Actual dissipation of energy in the dymp circuit is seen as heat in a stainless steel resistor. Since at maximum coil current it is desired to see only approximately 300 volts across the dump resistor, the resistance value required is $0.15 \Omega$. Also, the temperature of the resistor must not rise to an unacceptable level when maximum dump energy input is I MJ.

Performing the conversion on the curve shown in Figure 8a to obtain the pulses shown in Figure $8 \mathrm{~b}$ and determining the transient thermal impedance of the resistor as described earlier, a maximum resistor temperature of $97^{\circ} \mathrm{C}$. is expersted when $T_{\text {dulluiul }}=25^{\circ} \mathrm{C}$. Since the insulation of cables attached to the resistor is rated for $75^{\circ} \mathrm{C}$, the conductors have been attached far enough away from the rcsistor to prevent overheating as described below.

\subsubsection{Construction}

The resistor used in the $300 \mathrm{~V}, 2 \mathrm{kA}$ application was an existing device constructed of parallel four foot lengths of $1 / 2$ inch diameter 304 stainless steel rods welded in series. Twenty-four such rods are refuired for $0.15 \Omega$ tontal resistance. See Reference 5.

Electrical connections are made via $1 / 2$ inch thick stainless steel plates welded to the rods. The entire device is insulated thermally and electrically from aluminum angle support members by $1 / 2$ inch thick strips of Marinite inserted between $2 " \times 2 " \times 1 / 4$ i" sections of a Tuminum angle. Sce Figure 9. 


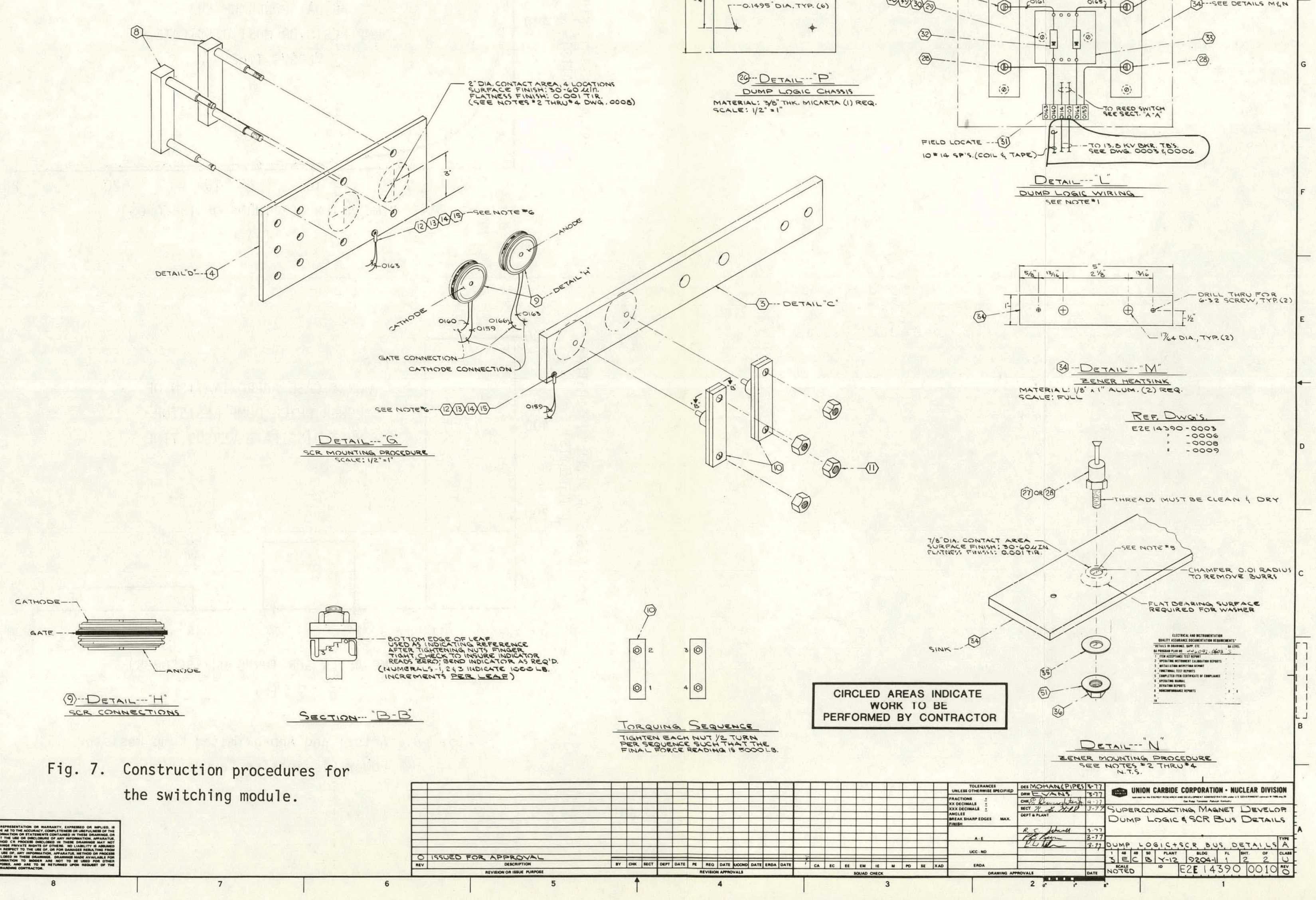




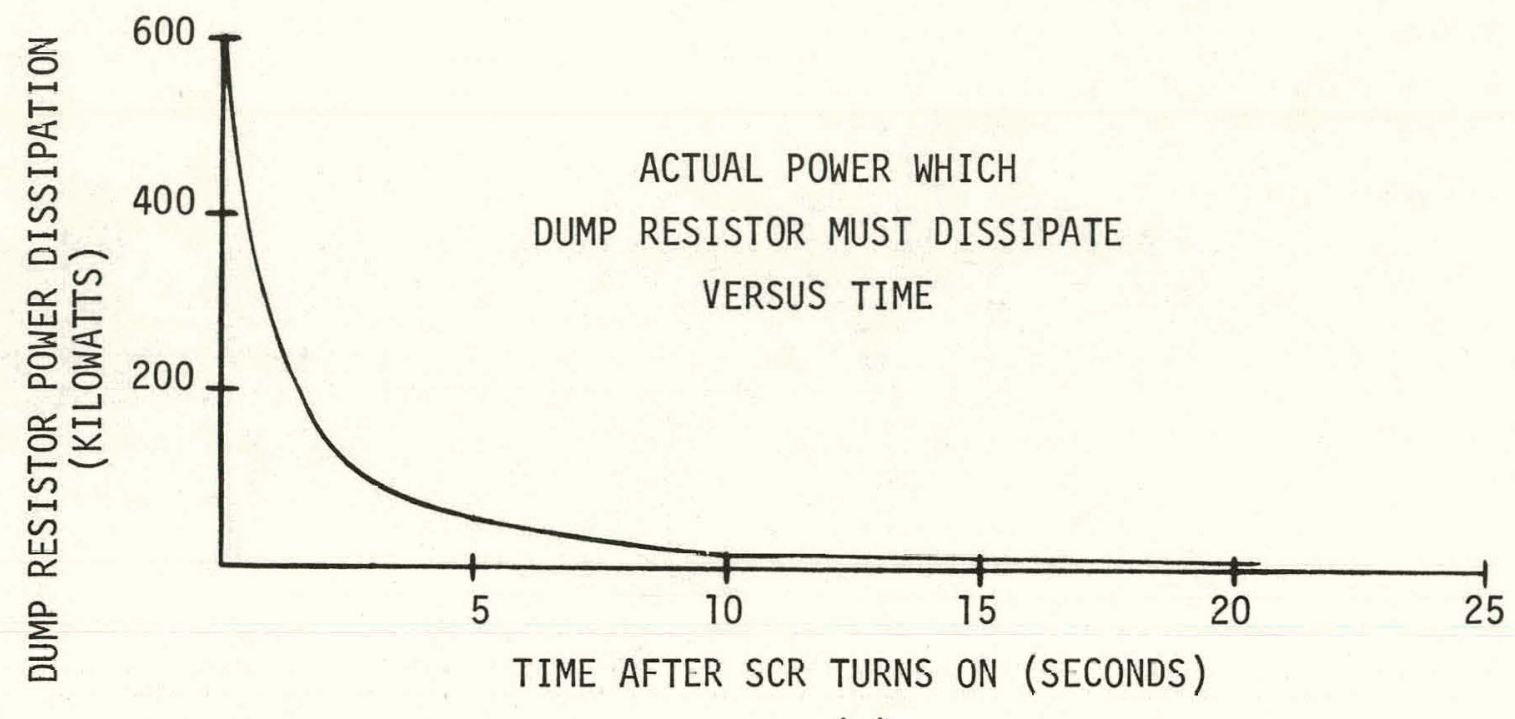

(a)

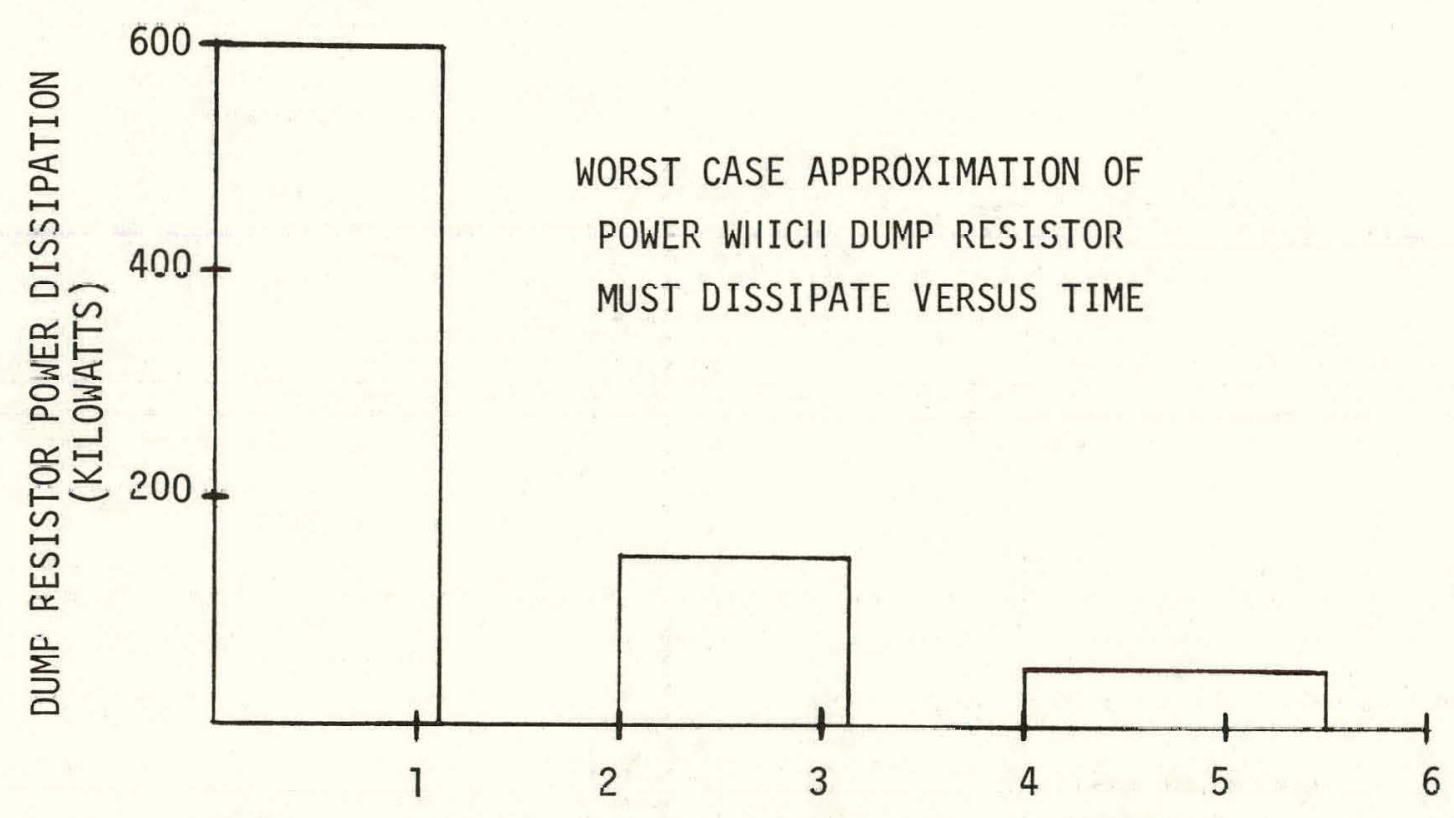

TIME AFTER SCR TURNS ON (SECONDS)

(b)

Fig. 8. Actual and Approximated Dump Resistor Power Dissipation Versus Time. 


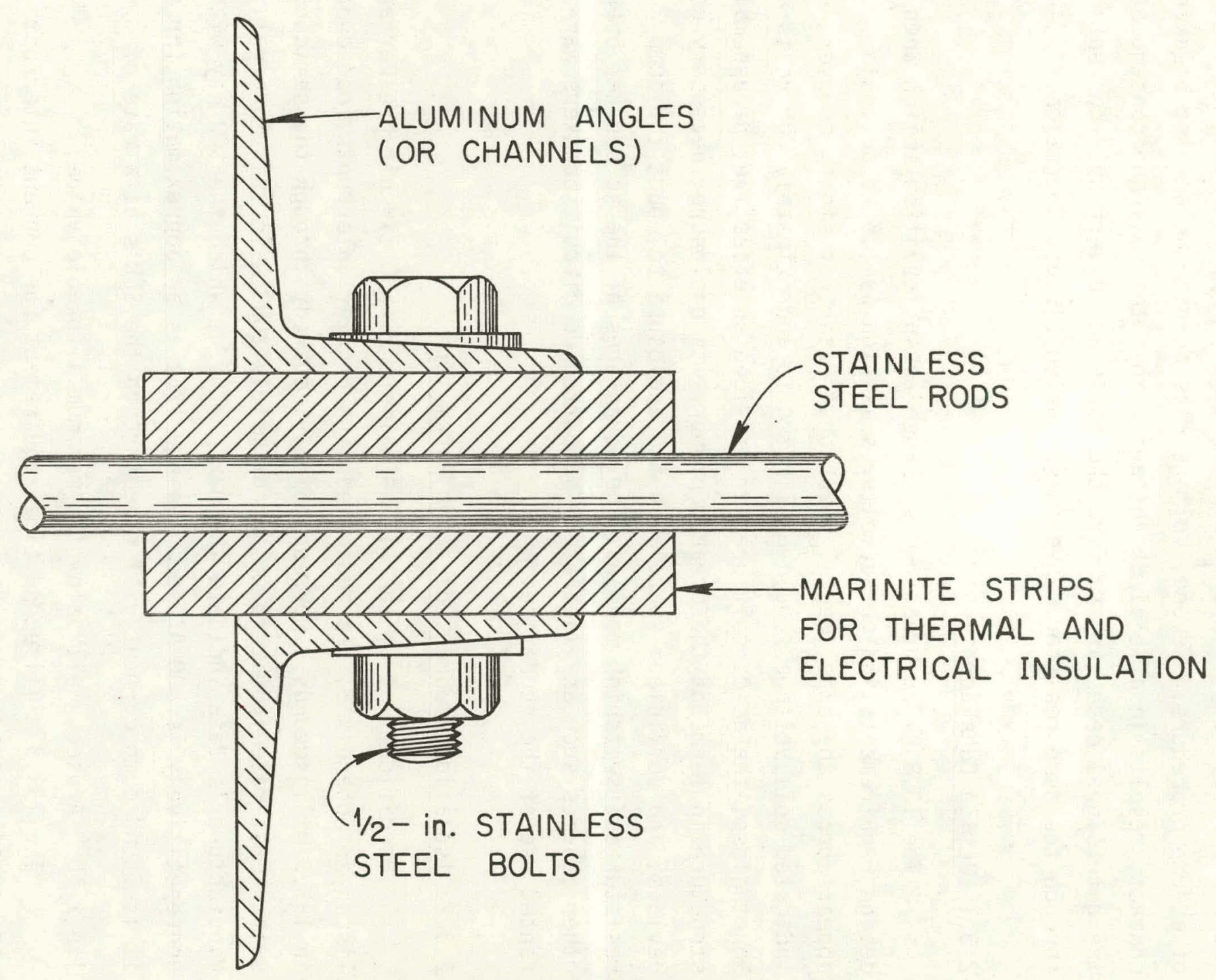

Fig. 9. Dump Resistor Support Detail. 


\subsection{THE ISOLATION BREAKER}

In Lhe present application, the role of the dump breaker is twofold. First, it isolates the power supply from the loadside conditions of a dump procedure. Second, voltage rise across the opening breaker contacts results in a $-\mathrm{L}$ di/dt voltage across the coil and consequently the gate signal necessary to fire the SCR's and divert coil current through the dump resistor. See "Description Circuit Operation."

\subsubsection{Design Considerations}

The $13.8 \mathrm{kV}$ ac breaker was chosen as an isolation switch when design requirements indicated voltages as high as $1.5 \mathrm{kV}$ dc could appear across the experimenlal inductor. Later revisions, however, indicated coil voltage should be limited to approximately 300 volts dc. Nonetheless, the ac circuit breaker provided an effective, preassembled structure in terms of the breaker proper, its enclosure, necessary control devices, and sufficient space atop the enclosure to mount the dump resistor and switching module. The advantages of the ac breaker over other schemes such as elaborately supported dc circuit breakers warranted use of the ac device.

\subsubsection{Isolation Breaker Operating Parameters}

Specifications of the Allis-Chalmers MC-500 circuit breaker are 1 isted in Appendix B. As indicated, the breaker interrupts load current in 133.3 milliseconds. Correspondingly, current through the semiconductor switch must rise from zero to approximately $2000 \mathrm{~A}$ in this interval. Manufacturer's data indicate the maximum di/dt which the SCR may withstand nonrepetitively is $800 \mathrm{~A} / \mu \mathrm{sec}$. Using $\Delta \mathrm{i} / \Delta \mathrm{t}$ as an approximation for $\mathrm{di} / \mathrm{dt}$, it is found dump current will rise through the SCR's at a rite of

$1.5 \times 10^{-2} \mathrm{~A} / \mu \mathrm{sec}$, well below the maximum allowable value.

The 133.3 millisecond time requirement for current interrupt also implies field energy dissipation before experimental coils are damaged by hot spot formation. For example, the time scale describing magnet heating characteristics during a quench depends upon the current 
density, magnetic field, and heat transfer characteristics of the magnet. Choosing the low representative values of maximum field $B_{m}=1.8$ tesla and current density $\mathrm{J}=1.7 \mathrm{kA} / \mathrm{cm}^{2}$, magnet temperatures will reach $100^{\circ} \mathrm{K}$ in four minutes and $300^{\circ} \mathrm{K}$ in 7.4 minutes when adiabatic heating at constant current is assumed. Higher representative values such as $B_{m}=8$ tesla and $J=4.2 \mathrm{kA} / \mathrm{cm}^{2}$ suggest a temperature of $100^{\circ} \mathrm{K}$ in only 24 seconds. ${ }^{6}$ Higher values for $B_{m}$ and $J$ therefore indicate sufficient isolation switch operating speed, but illustrate the need for automatic dump signals as described in the next section. 


\section{DUMP STAGING}

\subsection{TRIGGER INPUTS}

Consideration of operating contingencies led to a list of conditions which, if existing, should initiate a signal to dump stored magnetic energy. The first condition is based on operator judgment. Should abnormal operation be observed, a manual switch may trigger the energy dump device. Second, should power supply output inversion fail to discharge a quenched inductor, the dump mechanism is automatlcally dclivated. Third, loss of primary power must initiate a dump command as line loss implies no utility grid for the inversion process. Fillally, a current sensing magnetic reed relay located at the semiconductur switching module insures full dump staging in the event a short current pulse passes through the SCR swilches or device failure permits excess leakage current through the dump device.

\subsection{OESCRIPTION .OF CIRCUIT OPERATION}

Ciicuit operation during a dump procedure is characterized first hy the opening of the isolation switch, second by consequent - Ldi/dt inductor voltage rise, and third by energy dissipation in the dump resistor. Considering dump breaker operation, Figure 3 indicates all the previously described trigger inputs provide a low resistance path across the trip lines of the $13.8 \mathrm{kV}$ dump breaker. The manual switches located at a remote control panel and at the dump breaker tie the trip coil ( 1 ine 25) directly across the 125 VDC battery supply, opening the circuit breaker.

Operation of the reed relay is morc subtle, however. First, as shown in Figure 10, the relay is pusitioned 30 as to be activated by field lines created by dump current. The relay used is designed to pult in $17.5 \pm 7.5$ ampere-turns magnetomotive force. Considering the bus in section $A-A$, Figure 10 , a's a single turn, the relay may not operate until a dump current of 25 amperes flows. To increase the sensitivity of the device, the field shunt (item 17, Figure 10) may be 


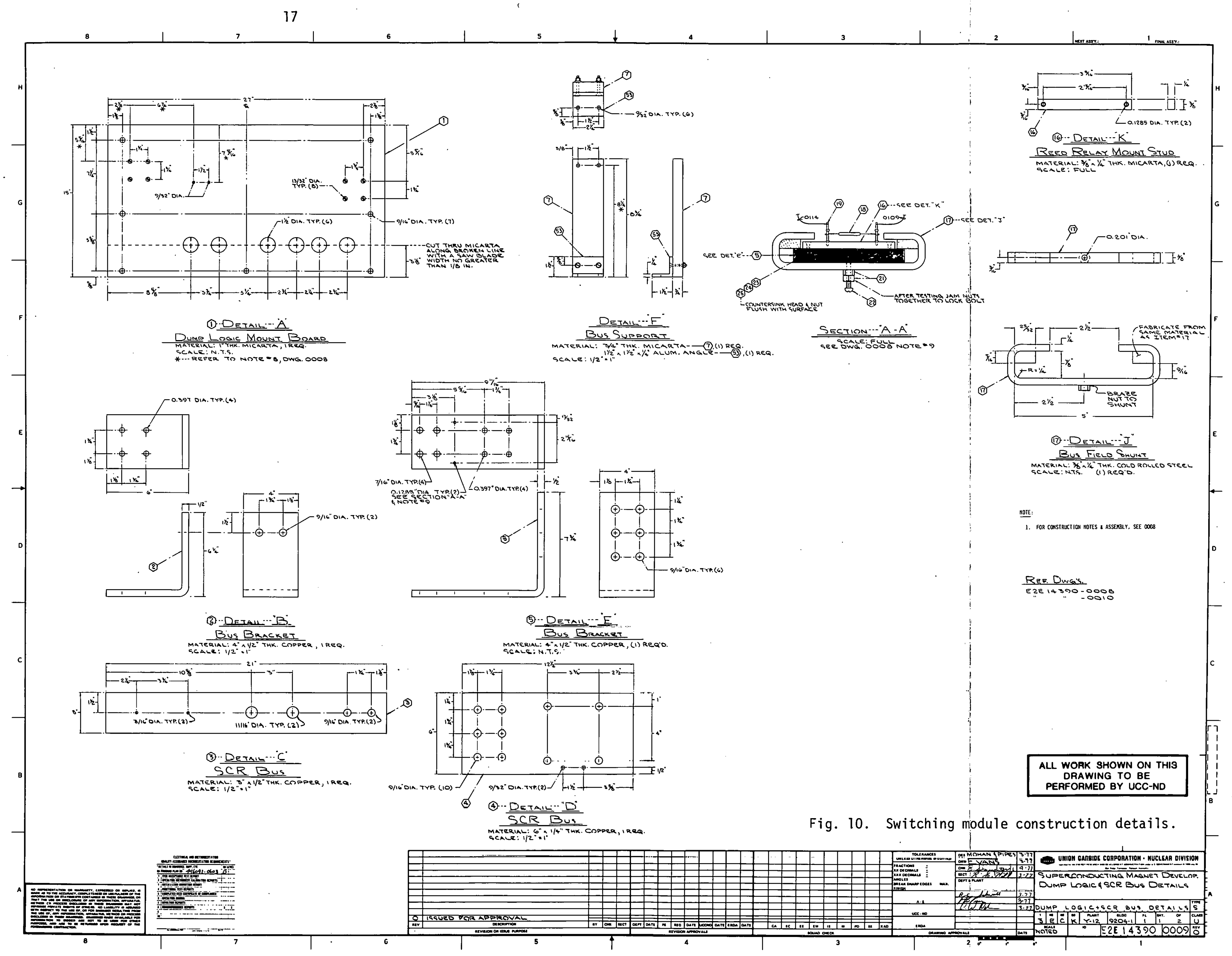


adjusted to control magnetization of the reed leaves and thus the current level necessary for operation. At required current, the reed relay contacts (RYD) touch, shorting out $I C R$, de-energizing the normally closed 1 CR relay contact in line 08, Figure 3 and tripping the dump breaker.

Third, loss of $2400 \mathrm{~V}$ utility power is detected by an undervoltage relay which opens the $27 \times$ relay contact in line 09 , Figure 3 . Control relay 2 CR de-energizes and the dump breaker is opened.

Fourth, a specially designed quench detector circuit may open the dump breaker. See Figure 11. By monitoring resistive voltage across an experimeinlal induclur, ${ }^{7}$ lle deleclur circult senses a quenchiny cuil and corrirlands power supply SCR's to phase back and route magnetic field energy back into the utility grid. If however, coil voltage does nut 1 te between $270 \mathrm{~V}$ and $330 \mathrm{~V}$ within a period of $80 \mathrm{mili}$ iseconds, the power supply is assumed to have failed to invert and contact 0 in line 07A closes. Subsequent dump staging is then identical to that in the event of an RYD contact closure. Next, should the $2400 \mathrm{~V}$ primary power circuit breaker open, the 52b contact in line 12 closes and trips the dump breaker.

Finally, if the integral contactor in the power supply is opened under load conditions, manufacturer provided circuils detect abriormal inductive voltage rise internal to the power supply and provide an output appropriate to activate the energy dump device.

Considering next semiconductor switch operation, assume wire rinulber 68 (Figure 3 ) is the positive leg and wire number 67 is the negative leg of the power supply. When the breaker contacts are closed, a very low voltage, positive on top, is seen across the inductor and both SCR's are in the off state. When the breaker contacts begin to open as a result of some trigger input, however, voltage on the coil reverses polarity and rises as the inductor attempts to maintain constant current. Voltage will continue to rise across the dump device and at $320 \mathrm{~V}$, the left hand series combination of IN3347, $160 \mathrm{~V}$, zener diodes will break over and gate current will be drawn in the left hand SCR. The gate signal is limited, however, by the $180 \Omega$ impedance of the 


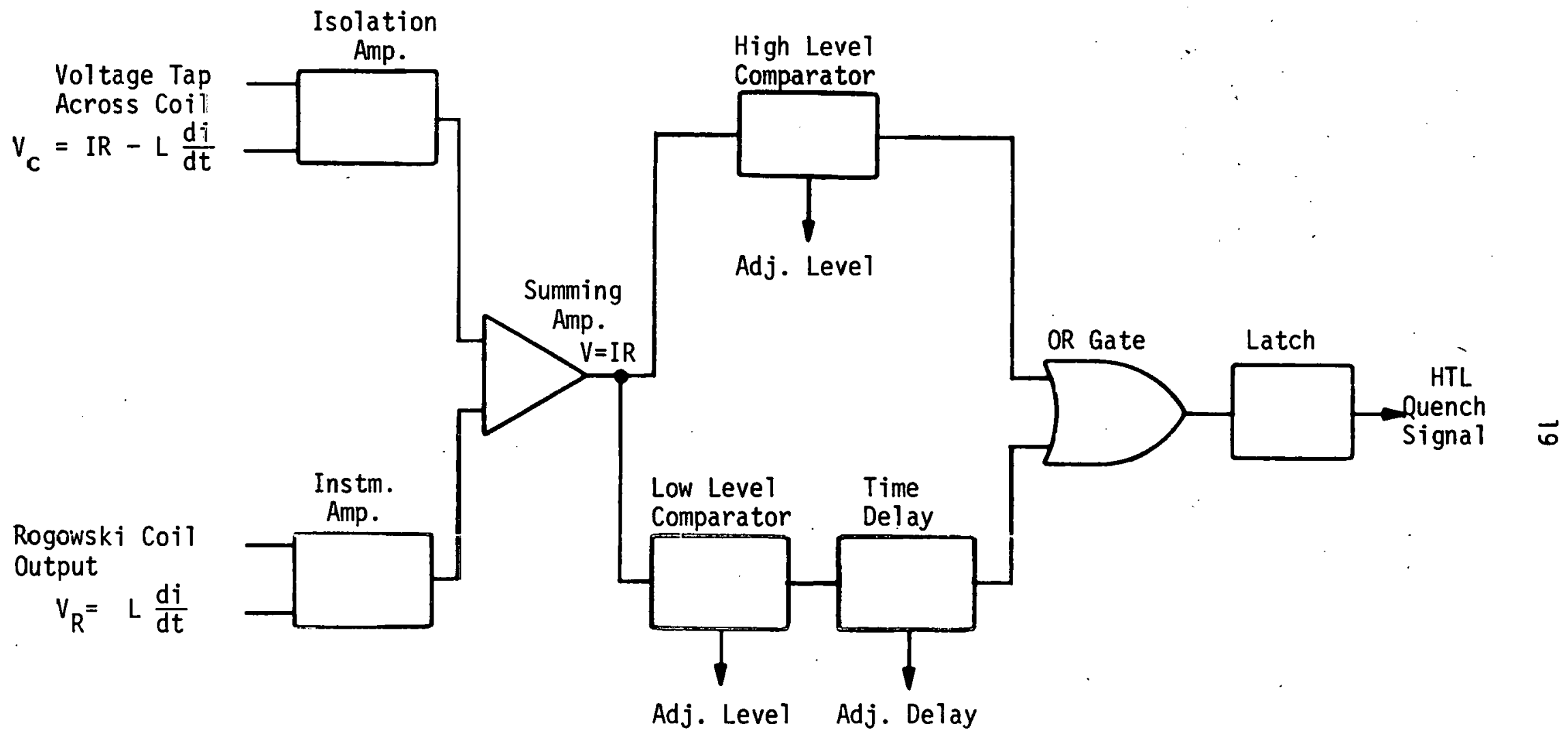

Fig. 11. Block Diagram of Voltage Tap Quench Detection Circuit (From Ref. 10) 
gate circuit.

Sillce llie SCR will trigger over a gate signal range from 100 to $200 \mathrm{~mA}\left(\mathrm{~V}_{\mathrm{D}}=12 \mathrm{~V}\right)$, worst case calculations indicate the left hand SCR will switch to the on state for coil voltages between $338 \mathrm{~V}$ and $356 \mathrm{~V}$. As the SCR begins conducting, coil current is diverted through the $0.15 \Omega$ dump resistor and magnetic field energy is converted to heat. Dissipation continues until dump current falls below the $150 \mathrm{~mA}$ holding current of the SCR.

Should the polarity of the power supply be reversed, an identical analys is of the right hand SCR and gate circuit is applicable. 


\section{CONCLUSION}

The problem of dealing with stored energy in a normal going superconducting magnet is significant. Unless coil current is shunted around the superconductors or energy is quickiy removed from the system, coil damage is likely. In the case of energy removal schemes, failure of the primary discharging technique requires a reliable energy dump device to insure maximum operating safety.

In the $300 \mathrm{~V}, 2 \mathrm{kA}$ design, magnetic field energy is dissipated as heat on signal from a variety of inputs ranging from manual triggering to line loss indication. The device effectively deals with the bipolar power supply by using a symmetrical semiconductor switching module in conjunction with a modified circuit breaker isolation switch and a stainless steel dump resistor. Reliability of the dump device is increased by the capability of the circuit to provide its own gate signal via voltage rise across the isolation switch.

Considerable streamlining, however, is possible in the design. For instance, commercial heatsinks could be used in place of the bus bars shown in Figure 7 so that less chance of improper assembly would exist. Simpler bus supports and connections could also be incorporated with a commercial heatsink installation.

As a final consideration, the dump device does not trigger immediately when a dump signal is received since isolation switch voltage rise is not. instantaneous. Delayed operation, however, is not severe enough to compromise design effectiveness because of the comparatively long time scale associated with temperature rise in a quenched superconducting magnet. ${ }^{6}$

The dump system described meets design requirements for the $300 \mathrm{~V}, 2 \mathrm{kA}$ installation and modification can permit other applications where rapid magnetic field energy removal is required. 


\section{APPENDIX A}

\section{Westinghouse}

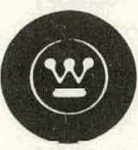

\section{SCR Data}

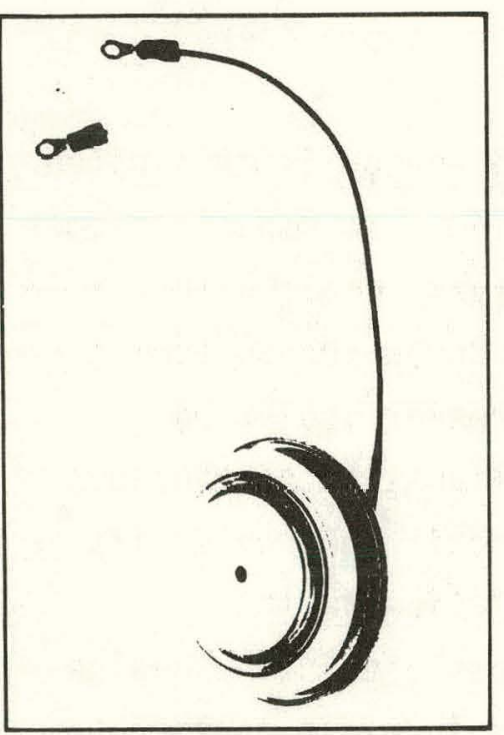

Features

- di/namic Gate design

- All diffused design

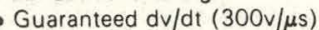

- Low gate current witn sott gate control

- Low VTM

Low Thermal Impedance

- High surge rurrent rapahility

- Compression Bonded Encapsulation

- $I^{2} t$ package rating

Pow R Dieo thyrietor paokago offora:

- Single or double-sided cooling

- Reversible mounting polarity

- Compact size and weight

- Long creepage \& strike paths

- Hermetic seal

Westinghouse Lifetime Guarantee

Westingliouse warrants to the origunal purchiase?

Westinghouse warrants to the original purchias

What will correct any celects in workmunsh

fuctory or, at its option. issue credit at the

urigunal purchase price, for any silicon puwo

semiconductor bearing this symbol t durnet

the life of the equipment in which it is orinually

installed, provided said device is used within

mimufacturer's published ratings and appliecl

in at:cordance with good engmeerning practice. di/namic Gate

Pow-R-Disc Thyristor

Silicon Controlled Rectifiers

Type T920

Forward Current 1415 to 1570 Amps RMS 900 to 1000 Amperes Half-Wave Average Forward Blockıng Voltages to 1600 Volts

\section{Dimensions in Inches}

(and Millimeters)

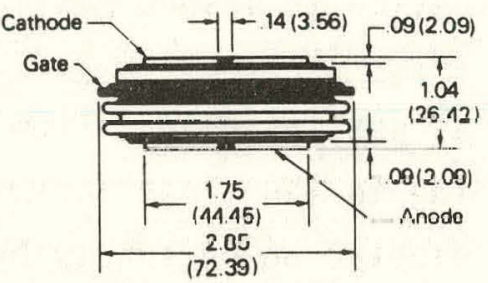

Approximate Weight $16 \mathrm{oz}$. (454 gms.)

Outline T92

Air-cooled and water-cooled heat exchangers are available.

Ordering Information

\begin{tabular}{|c|c|c|c|c|c|c|c|c|c|c|}
\hline Iype & \multicolumn{2}{|c|}{ Voltage } & \multicolumn{2}{|c|}{ Eurrent } & \multicolumn{2}{|c|}{ Turn off } & \multicolumn{2}{|c|}{ Gate eurrent } & \multicolumn{2}{|c|}{ Leads } \\
\hline Code & $\begin{array}{l}\text { VDRM } \\
\text { and } \\
\text { VHRM } \\
(V)\end{array}$ & Code & $\begin{array}{c}{ }^{1} T(\text { iw } \\
(A) \\
(A)\end{array}$ & Code & $\stackrel{\operatorname{tn}}{\mu \mathrm{sec}}$ & Code & $\begin{array}{l}{ }^{\text {IGT }} \\
\text { (ma) }\end{array}$ & Code & Case & Code \\
\hline T020 & $\begin{array}{r}100 \\
200 \\
300 \\
400 \\
500 \\
600 \\
700 \\
800 \\
900 \\
1000 \\
1100 \\
1200 \\
1400 \\
1600\end{array}$ & $\begin{array}{l}01 \\
02 \\
03 \\
04 \\
05 \\
06 \\
07 \\
08 \\
09 \\
10 \\
11 \\
12 \\
14 \\
16\end{array}$ & $\begin{array}{r}000 \\
1000\end{array}$ & $\begin{array}{l}00 \\
10\end{array}$ & $\begin{array}{c}150 \\
\text { (typical) }\end{array}$ & 0 & 200 & 3 & T02 & DW \\
\hline
\end{tabular}

\section{Example}

Obtain optimum device performance for your application by selecting proper order code.

Type $T 920$ rated at $1000 \mathrm{~A}$ averacje with $V_{D R M}=1000 \mathrm{~V}$ 


\section{di/namic Gate}

Pow-R-Disc Thyristor

\section{Silicon Controlled Rectifiers}

Type T920

Forward Current 1415 to 1570 Amps RMS

900 to 1000 Amperes Half-Wave Average

Forward Blocking Voltages to 1600 Volts

\section{Voltage}

\begin{tabular}{|c|c|c|c|c|c|c|c|c|c|c|c|c|c|c|c|}
\hline lock| & & & & & & & & & & & & & & & \\
\hline Repetitive peak forward blocking voltage , $V \ldots$ & VDRM & 100 & 200 & 300 & 400 & 500 & 600 & 700 & 800 & 900 & 1000 & 1100 & 1200 & 1400 & 1600 \\
\hline Repetitive peak reverse voltage(8) $v \ldots \ldots \ldots$. & $V_{\text {RRM }}$ & 100 & 200 & 300 & 400 & 500 & 600 & 700 & 800 & 900 & 1000 & 1100 & 1200 & 1400 & 1600 \\
\hline $\begin{array}{l}\text { Non-repetitive transient peak reverse voltage, } \\
\forall \leq 5.0 \mathrm{msec} \ldots \ldots \ldots \ldots \ldots \ldots \ldots \ldots \ldots \ldots \ldots\end{array}$ & $V_{\text {ASM }}$ & 200 & 300 & 400 & 500 & 600 & 700 & 800 & 900 & $|1000|$ & $|1100|$ & $|1200|$ & $|1300|$ & 1500 & 1700 \\
\hline $\begin{array}{l}\text { Forward leakage current, } m A \text { peak } \ldots \ldots \ldots \ldots \\
\text { Reverse leakege current, } m A \text { peak } \ldots \ldots \ldots \ldots\end{array}$ & $\begin{array}{l}\text { IDRM } \\
\text { IRRM }\end{array}$ & & & & & & & & & & & & & & \\
\hline
\end{tabular}

\section{Current}

Conducting State Maximums
$\left(T_{J}=125 \mathrm{C}\right)$

\begin{tabular}{|c|c|c|c|}
\hline$T_{j}=$ & Symbol & $15<0=00$ & $1920-10$ \\
\hline AMS forward current, $A$ & $\mathrm{I}_{\mathrm{T}}$ & 1415 & 1570 \\
\hline Ave. forward current, A ........ & ITI & 900 & 1000 \\
\hline One-half cycle surge current(3. A .. & ITSM & 25,000 & 27.000 \\
\hline 3 cycle surge current(8) A & ITSM & 18,700 & 20,200 \\
\hline 10 cycle surge currento. A & I TSM & 15,400 & 16,700 \\
\hline$I^{2} t$ for fusing $(t=8.3 \mathrm{~ms}) A^{2} \mathrm{sec}$ & & $2,600,000$ & $3,040,000$ \\
\hline Max $\left.\right|^{2} t$ of package $(t=8.3 \mathrm{~ms}), A^{2} \mathrm{sec}$ & $12+$ & $90 \times 10^{6}$ & $90 \times 10^{\circ}$ \\
\hline $\begin{array}{l}\text { Forward volsage drop at I } \mathrm{TM}=1500 \mathrm{~A} \\
\text { and, } T_{\mathrm{J}}=25^{\circ} \mathrm{C}, \mathrm{V} \ldots \ldots \ldots \ldots\end{array}$ & $\mathrm{v}_{\mathrm{TN}}$ & 1.55 & 1.35 \\
\hline
\end{tabular}

Switching

$\left(\mathrm{T} J=25^{\circ} \mathrm{C}\right)$

Turn-off time. IT $=250 \mathrm{~A}$

$\mathrm{TJ}=125^{\circ} \mathrm{C} . \mathrm{diA} / \mathrm{dt}=50$

A/ $\mu$ sec respplied $d v / d t=$

$20 \mathrm{~V} / \mu \mathrm{sec}$ linear to 0.8 VDRM. $\mu \mathrm{sec} .$. . to

Turn-On and Delay Tim

$T M=1000 A$ (C). $t \mathrm{p}=450 \mu \mathrm{sec} . \ldots .$. ton

$V_{D}=600 \mathrm{~V}, \mu \mathrm{sec} \ldots \ldots \ldots \ldots \ldots$ td

Critical dv/dt exponential to VDRM

$T J=125^{\circ} \mathrm{C} . V / \mu \sec (\mathrm{D} \ldots \ldots \ldots \ldots . d v / d t$

di/dt@non-repetitive, JEDEC Std. \#7

Sec. 5.1.2.4. $A_{\mu} \mathrm{sec}$.

tatching Currento

Latching Current

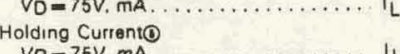

Symbol Min Typ Max

Min

(d)

$150 \quad 250$

\section{Gate}

\section{$\left(T_{J}=25^{\circ} \mathrm{C}\right)$}

Symbol Min Typ Max

Gate current to trigger at $V_{D}=12 \mathrm{~V}, \mathrm{~mA}$. . IGT Gate voltage to trigger at $V_{D}=12 \mathrm{~V}, \mathrm{~V} \ldots . V_{G T}$ Non-triggering gate voltage, $T_{J}=125^{\circ} \mathrm{C}$, and rated $V_{D R M}, V \ldots \ldots \ldots \ldots \ldots, V_{G D M}$ Non-triggering Gate Current at

$V_{D}=12 \mathrm{~V}, \mathrm{~mA} \ldots \ldots \ldots \ldots \ldots \ldots \ldots \ldots \ldots \ldots$ IGN Peak forward gate current, $A \ldots \ldots \ldots$ IGTM Peak reverse gate voltage, $V \ldots \ldots \ldots \ldots$ V V

Peak gate power, Watts........... PGM Average gate power, Watts.......... $\mathrm{PG}$ (av)

$\begin{array}{rr}\text { Min } & \text { Max } \\ 1.5 & 200 \\ & 3.0 \\ & \end{array}$

20

Thermal and Mechanical symbol Oper. junction temp., ${ }^{\circ} \mathrm{C} \ldots \ldots \ldots \ldots \ldots \mathrm{T}_{\mathrm{J}}$ Storage temp., ${ }^{\circ} \mathrm{C} \ldots \ldots \ldots \ldots \ldots \ldots, \mathrm{T}_{\mathrm{stg}}$ Mounting force, lb. (1) . . . . . . . . . . . . Thermal resistance

with double sided cooling (1).........

Junction to case, ${ }^{\circ} \mathrm{C} /$ Watt.......... R R JC Case to sink, lubricated, ${ }^{\circ} \mathrm{C} /$ Watt. ...... R R CS

\begin{tabular}{rrr} 
Min & Typ & Max \\
\hline-40 & & 125 \\
-40 & & 150 \\
5000 & & 5500 \\
& & \\
& & \\
& .028 & .03 \\
.008 & .09
\end{tabular}

(1) For information on Mounting Procedures and Techniques refer to AD 54.050. 2) Applies for zero or negative gate voltage.

(1) With renz., wint

(3) JEDEC Standards 6.201.1.6 and 6.201.1.7. 
Technicól Data 54-568

dl/namic Gate

Pow-R-Disc Thyristor

Silicon Controlled Rectifiers

Typo T920__09

Forward Current 1415 Amps RMS

900 Amperes Half-Wave Average

Forward Blocking Voltages to 1600 Volts
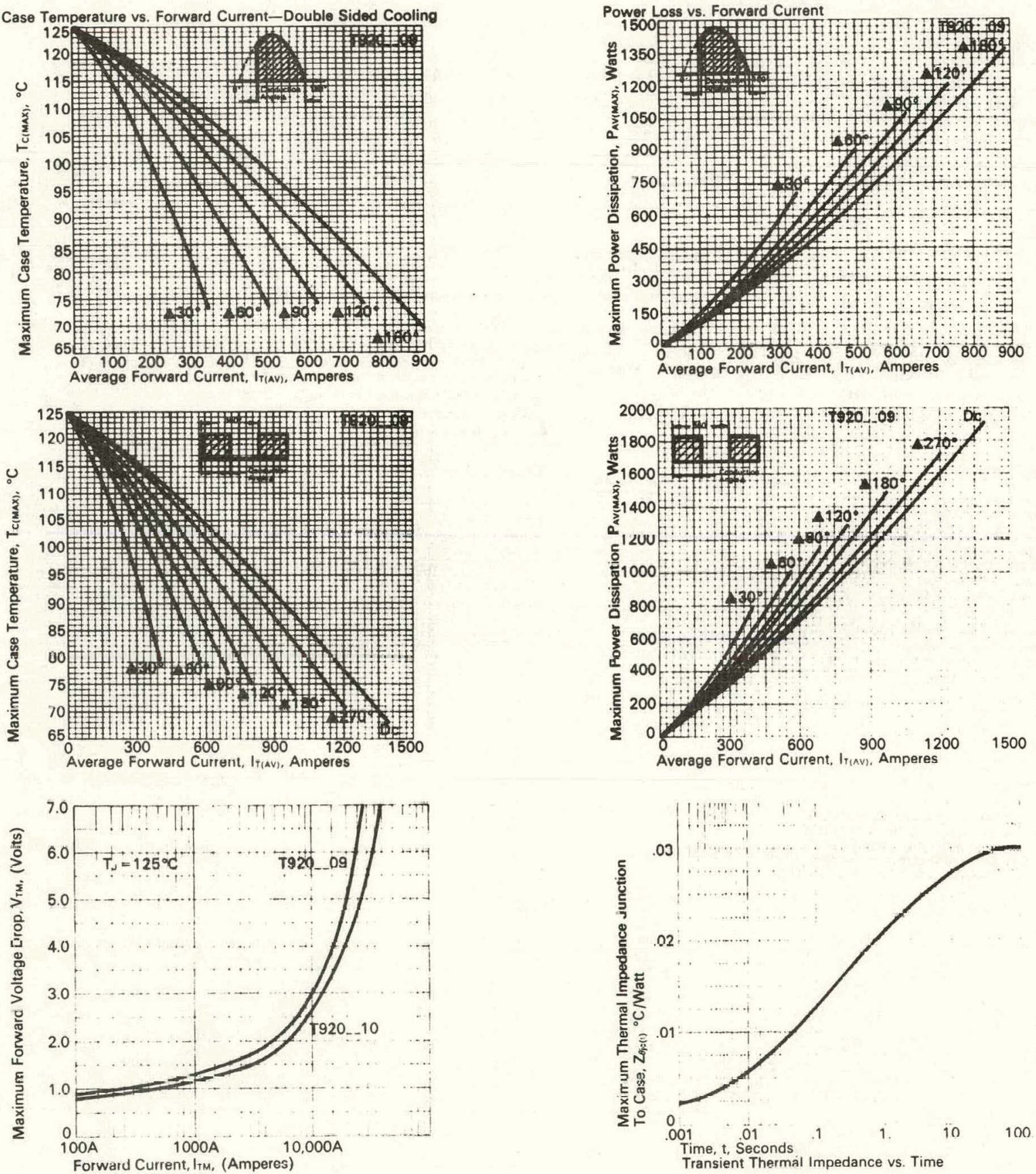
Technical Data 54-568

\section{di/namic Gate}

Pow-R-Disc Thyristor

Silicon Controlled Rectifiers

Type T920_-10

Forward Current 1570 Amps RMS

1000 Amperes Half-Wave Average

Forward Blocking Voltages to 1600 Volts
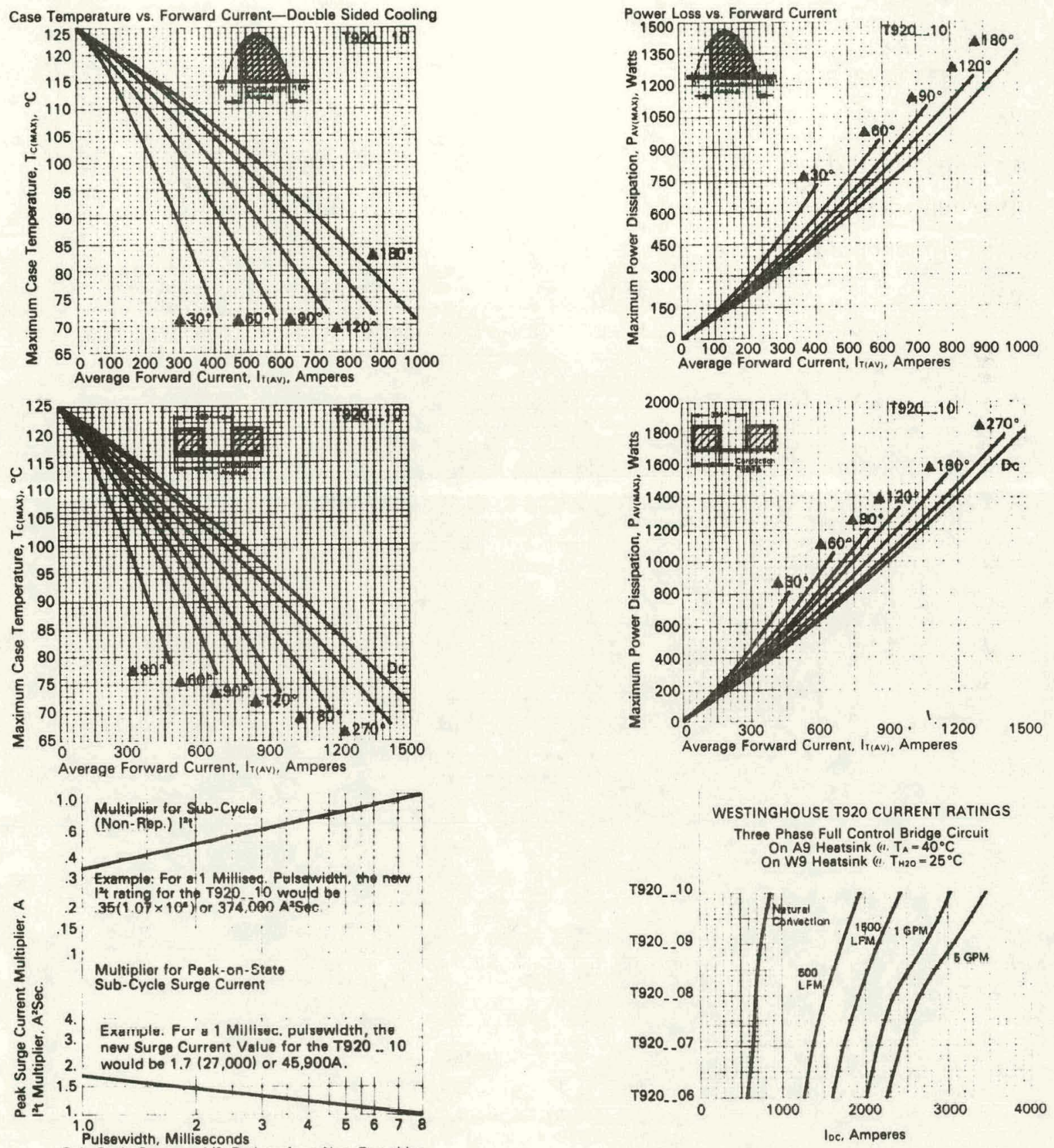

Sub-Cycle Surge and $\mathrm{I}^{\mathrm{a}} \mathrm{t}$ Ratings for a Non-Repetitive Half-Sine Wave

Westinghouse Electric Corporation

Semiconductor Division, Youngwood, Pa. 15697

Printed in U.S.A. 


\section{APPENDIX B}

\section{Allis-Chalmers Circuit Breaker Data}

Type

Rated Volts

Rated amps,

$3 \emptyset$ at 13,800 volts

MVA

Max. design volts

Inlerrupt amps at rated volts

Rated interrupting time, cycles Weight, Lbs.
MC 500

13,800

1,200

500

15,000

21,000

8

1,650 
APPENDIX C

Elementary Diagram Symbol Legend and Numbering System

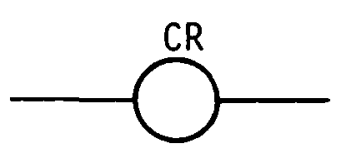

SYMBOL LEGEND

CONTROL RELAY COIL

*

PILOT LIGHT $(*$ = CAP COLOR)

$-\mathrm{HF}$

RELAY CONTACT, NORMALLY OPEN (N.O.)

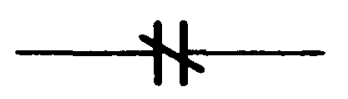

RELAY CONTACT, NORMALLY CLOSED (N.C.)

$-\frac{1}{0}$

PUSH BUTTON SWITCH, MOMENTARY, N.0.

$\longrightarrow$

PUSH BUTTON SWITCH, MOMENTARY, N.C.

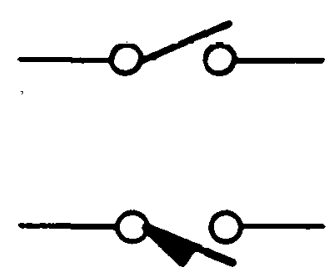

SWITCH, N.O.

$\longrightarrow$

RESISTOR, FIXED, VALUE (IN OHMS) ADJACENT TO SYMBOL

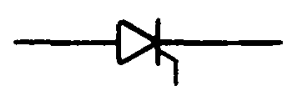

LIMIT SWITCH, N.0.

SILICON CONTROLLED RECTIFIER 
APPENDIX C (continued)

SYMBOL LEGEND

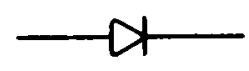

DIODE

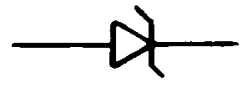

ZENER DIODE

WIRE NUMBERING SYSTEM

WIRE NUMBERS ARE SHOWN ON EACH SHEET AS TWO-DIGIT NUMBERS: (E.G. 01, $02,10,42$, ETC.). IN ALL CASES, THE COMPLETE WIRE NUMBER (WHICH APPEARS ON THE ACTUAL WIRES IN THE EQUIPMENT AND ON THE TERMINAL BOARDS) IS A 4-DIGIT NUMBER. THE FIRST TWO DIGITS INDICATE THE NUMBER OF THE ELEMENTARY DIAGRAM SHEET ON WHICH THE WIRE ORIGINATES AND THE LAST TWO DIGITS INDICATE THE WIRE ON THAT. SHEET. THUS 0342 INDICATES WIRE NUMBER 42 ORIGINATING ON SHEET 03 OF THE DIAGRAM.

\section{MAPPING SYSTEM}

1. IN THE MARGIN OF THE DIAGRAM, BESIDE EACH DEVICE OPERATING COIL, TWO NUMERALS SEPARATEN RY A DASH AND FNCI ISFD IN PARFNTHFSFS ( ) ARE. SHOWN. THE FIRST NUMBER GIVES THE TOTAL NUMBER OF NORMALLY OPEN CONTACTS ON THE DEVICE. THE SECOND NUMBER (UNDERSCORED) GIVES THE TOTAL NUMBER OF NORMALLY CLOSED CONTACTS ON THE DEVICE.

2. AGAIN, IN THE MARGIN OF THE DIAGRAM, ONE OR MORE 4-DIGIT NUMBERS ARE SHOWN. THESE NUMBERS GIVE THE LOCATION OF THE DEVICE CONTACTS. THE FIRST TWO DIGITS INDICATE THE SHEET NUMBER AND THE LAST TWO DIGITS, THE LINE NUMBER WHERE THE CONTACT WILL BE FOUND. IF THE 4-DIGIT NUMBER IS UNDERSCORED, IT INDICATES TIIE CONTACT IS NORMALLY CLOSED; IF NOT UNDERSCORED, THE CONTACT IS NORMALLY OPEN, THUS:

0362 INDICATES A NORMALLY OPEN CONTACT, LOCATED ON LINE 62 OF SHEET 
3 OF THE ELEMENTARY DIAGRAM.

0364 INDICATES A NORMALLY CLOSED CONTACT, LOCATED ON SHEET 03, LINE 64.

3. UNDER EACH CONTACT, A 4-DIGIT NUMBER IS SHOWN IN BRACKETS. THIS NUMBER INDICATES THE SHEET AND LINE NUMBERS WHERE THE OPERATING COIL OF THE DEVICE WILL BE FOUND.

4. WHERE A WIRE IS CONTINUED FROM ONE DIAGRAM SHEET TO ANOTHER, A 4-DIGIT NUMBER IN BRACKETS IS SHOWN AT THE END OF THE WIRE. AGAIN, THIS NUMBER INDICATES THE SHEET AND LINE NUMBERS WHERE THE WIRE CONTINUES. 


\section{REFERENCES}

1. I. M. Firth, Superconductivity, London: Mills and Boon Limited, 1972 , p. 8.

2. G. Woods, "Coil Energy Dump Systems," ORNL Superconducting Magnet Development Note \#193, Sept., 1975.

3. W. A. Fietz, C. H. Rosner, "Advances in Superconductive Magnets and Materials," IEEE Transactions, Vol. MAG-10, No. 2, June 1974, pp. 239-259.

4. GE SCR Manual, third edition, 1964, pp. 21-31, pp. 279-282.

5. G. W. Donaldson, "Dump Resistors Up to One Giga Joule," ORNL Engineering Sciences Memo No. 197, March 1976.

6. H. T. Yeh, "Considerations of Coil Protection and Electrical Connection Schemes in Large Superconducting Toroidal Magnet System," ORNL Technical Memo No. 5043, March 1976.

7. S. Y. Hsieh, et al., "Summary of Existing Superconducting Magnet Experience and Its Relevance to the Safety of Fusion Magnet," Proc. of 6th Symp. on Engr. Prob. of Fusion Research, San Diego, Nov., 1975, pp. 116-119.

8. Westinghouse Technical Data 54-568, Feb., 1975, pp. 39-42.

9. Westinghouse SCR Designer's Handbook, second edition, 1970, pp. $10-10 \& 10-11$.

10. J. Guddard, ORNL, prifvate cummunledtlun. 
ORNL/TM-5892

INTERNAL DISTRIBUTION

1. Myer Bender

2. J. F. Clarke

3-7. R. E. Hill

8. M. S. Lubell

9. R. V. Miskell

10-19. M. J. Mohan

20. F. S. Patton

21. E. W. Pipes

22. R. E. Schwall

23-24. H. G. Smith

25. A. J. Thompson

26-27. Laboratory Records.

28-29. Central Research Library

30. Document Reference Section

31. Laboratory Records, ORNL - RC

32. ORNL Patent Office

33-34. Fusion Energy Division Library

35. Fusion Energy Division Reports Office

EXTERNAL DISTRIBUTION

36. Director, Research \& Technical Support Division, ERDA-ORO

37=63. Technical Information Center, P.0. Box 62, Oak Ridge, TN 37830

64-66. Dr. C. A. Rodenberger, P.E. Cooperative Education Director Room 204 Zachry Texas A\&M University College Station, Texas 77843 